\title{
Time-dependent appearance of myofibroblasts in granulation tissue of human skin wounds
}

\author{
P.Betz ${ }^{1}$, A. Nerlich ${ }^{2}$, J. Wilske ${ }^{1}$, J. Tübel ${ }^{1}$, R.Penning ${ }^{1}$, and W. Eisenmenger ${ }^{1}$ \\ Departments of ${ }^{1}$ Legal Medicine and ${ }^{2}$ Pathology, University of Munich, Frauenlobstrasse 7a, W-8000 München 2 , \\ Federal Republic of Germany
}

Received January 6, 1992 / Received in revised form March 27, 1992

\begin{abstract}
Summary. Human skin wounds (66) inflicted between $20 \mathrm{~h}$ and 7 months prior to biopsy were studied. In order to identify the type of cellular differentiation of the fibroblastic cells in the granulation tissue, alpha-smooth muscle actin and desmin were immunohistochemically localized. The value of any presumed time-dependent appearance and/or disappearance of positively stained cells was tested for the estimation of wound age. In skin specimens with a wound age less than 5 days $(n=15)$ no typical granulation tissue had developed and no alphaactin-positive myofibroblasts could be detected. The first appearance of positively reacting myofibroblasts was noted in a 5-day-old wound. In $57 \%$ of the lesions with a wound age between 5 and 31 days ( 25 out of 44 cases) typical granulation tissue formation was present and myofibroblasts with positive reaction for alphasmooth muscle actin could be identified. Numerous positively reacting cells could generally be found in wounds aged between 16 and 31 days, but also in wounds less than 16 days old. In $29 \%$ of the cases with a wound age of more than 31 days ( 2 out of 7 cases) alpha-sma-positive myofibroblasts also occured. Fibroblastic cells positive for desmin could not be seen at all in our series. Our results demonstrate the appearance of alpha-sma-positive myofibroblasts with the initial formation of typical granulation tissue in human skin lesions as early as approximately 5 days after wounding. In contrast to recent experimental results these cells remained detectable in wounds aged more than 2 months in some cases. The immunohistochemical detection of actin-positive cells, therefore, demonstrates whether an unknown skin wound is aged approximately 5 days or more. Even though a time-dependent decrease of myofibroblasts in human granulation tissue after 31 days in human wounds seems probable, the extended presence (up to about 2 months) of these cells allows no further exact age determination of older wounds.
\end{abstract}

Key words: Myofibroblasts - Alpha-smooth muscle actin - Desmin - Immunohistochemistry - Wound age

This study was supported by a grant from the "Deutsche Forschungsgemeinschaft" (grant Ei 209/3-1) and by a grant from the "Friedrich-Baur-Stiftung", University of Munich, FRG.

Correspondence to: P. Betz
Zusammenfassung. Es wurden 66 menschliche Hautwunden mit einem Wundalter zwischen 20 Stunden und 7 Monaten sowie komplikationsloser Wundheilung ausgewertet. Nach immunhistochemischer Darstellung von alpha-Aktin und Desmin wurde das zeitabhängige Auftreten positiv reagierender Myofibroblasten im Wundgebiet untersucht. Es zeigte sich hierbei, daß in Hautwunden mit einem Wundalter unter 5 Tagen keine positiv anfärbbaren Zellen zu beobachten waren. In 57\% (25 von 44 Fällen) der Hautverletzungen, die zwischen 5 und 31 Tagen überlebt worden waren, fanden sich im Granulationsgewebe alpha-Aktin haltige Myofibroblasten. Besonders zahlreiche, positiv reagierende Zellen traten zwischen ca. 16 bis 31 Tagen nach Wundsetzung auf, konnten jedoch auch bereits in Hautwunden jüngeren Alters beobachtet werden. In 2 von 7 Fällen mit einem Wundalter zwischen 1 und 7 Monaten (29\%) liesen sich ebenfalls alpha-Aktin positive Myofibroblasten im Wundgebiet nachweisen. Desmin-haltige Myofibroblasten konnten nicht beobachtet werden. Die Ergebnisse zeigen, daß alpha-Aktin positive Myofibroblasten bereits mit Ausbildung typischen Granulationsgewebes ab ca. dem 5.Tag nach Verletzung im Wundgebiet auftreten. Der Nachweis positiv reagierender Zellen im Wundgebiet läßt jedoch aufgrund der Variabilität der Befunde keine weitere Differenzierung des Wundalters zu. Da alpha-Aktin-positive Myofibroblasten im Untersuchungsgut auch noch in einer Hautwunde mit einem Alter von 2 Monaten und 13 Tagen beobachtet werden konnten, ist die im Tierexperiment gefundene maximale Nachweisbarkeitsdauer von 30 Tagen auf das Granulationsgewebe menschlicher Hautwunden nicht übertragbar.

Schlüsselwörter: Myofibroblasten - Alpha-Aktin - Desmin - Immunhistochemie - Wundalter

\section{Introduction}

The process of wound healing can be divided into an early exsudative phase followed by an inflammatory re- 
sponse and later on by fibro-proliferative processes. Older wounds are characterized by these fibro-proliferative processes which consist of typical granulation tissue containing numerous spindle-shaped cells. These fibroblastic cells actively produce various matrix components such as fibronectin, proteoglycans, and especially various collagen types. These play an important role in tissue rearrangement and the restitution of the biochemical properties of the tissue. Apart from the usual matrixsynthesizing "resting" fibroblast, a specialized subtype of fibroblastic cells with contractile properties, the socalled myofibroblasts, has been identified in healing wounds. These myofibroblasts show some features intermediate between fibroblasts and smooth muscle cells as demonstrated by immunohistochemical and electron microscopical studies and they are presumed to be involved in wound contraction $[8,11,19]$.

In experimental studies it has been demonstrated that myofibroblasts are immunologically reactive with alphasmooth muscle actin and show a time-dependent appearance and disappearance in the granulation tissue of skin wounds in rats. This indicates their possible application as a marker for the determination of the duration of healing wounds in man.

The present immunohistochemical study was performed to investigate the appearance and disappearance of these cells within the granulation tissue of human skin wounds of known duration and to investigate whether the immunohistochemical detection of these cells can be used as a reliable estimate of wound age in man.

\section{Material and methods}

Skin wounds (66 surgical wounds and lacerations after surgical treatment) with wound ages between $20 \mathrm{~h}$ and 7 months were obtained at autopsy within 3 days after death. We selected for this study only those wounds without apparent pathological abnormalities such as hypertrophic scar tissue, keloid formation or development of granulomas. The individuals died from traumatic events (car accidents, falls) and were between 15 and 92 years old, with an average age of 56 years. Only individuals without severe diseases which could have an influence on wound healing, such as cancer, metabolic diseases or malnutrition, were selected. According to clinical reports no substances such as glucocorticoids or cytotoxic agents which could have an effect on wound healing were administered during therapy. Three specimens of each skin wound were fixed in $4 \%$ PBS-formaldehyde and embedded in paraffin. Serial sections $(2-3 \mu \mathrm{m})$ were prepared for routine staining $(H \& E)$ and for immunohistochemistry. Specific monoclonal antibodies against alpha-smooth muscle actin and desmin were obtained commercially (Dako, Hamburg, Germany). For the detection of alpha-smooth muscle actin the sections were enzymatically pretreated with $0.1 \%$ trypsin as recommended by the manufacturer. Alpha-smooth muscle actin and desmin were visualized using the ABC-method (avidin-biotin-complex method) [10] and the APAAPmethod (alkaline phosphatase-anti alkaline phosphatase method) [5].

Normal skin specimens from the same patients and sections without the inclusion of the primary antibody were used as controls.

All sections were evaluated by light microscopy. Smooth muscle cells and pericytes of small blood vessels which stained positively served as internal controls for the staining reaction. Only those cells staining within the granulation tissue and which were not in topographical relation to blood vessels or capillaries were regarded as "myofibroblasts".

A semiquantitative evaluation was performed (magnification $300 \times$ ) and positively reacting myofibroblasts in 3 areas of each specimen were counted and the average value was estimated. Skin wounds showing no positively reacting cells were classified as group 0 , specimens with less than 5 alpha-sma-positive myofibroblasts per microscope field as group 1 and skin wounds containing more than 5 positive cells as group 2 .

\section{Results}

\section{Normal skin}

In normal skin alpha-actin was detectable in the cytoplasm of pericytes of blood vessels, in the smooth muscle

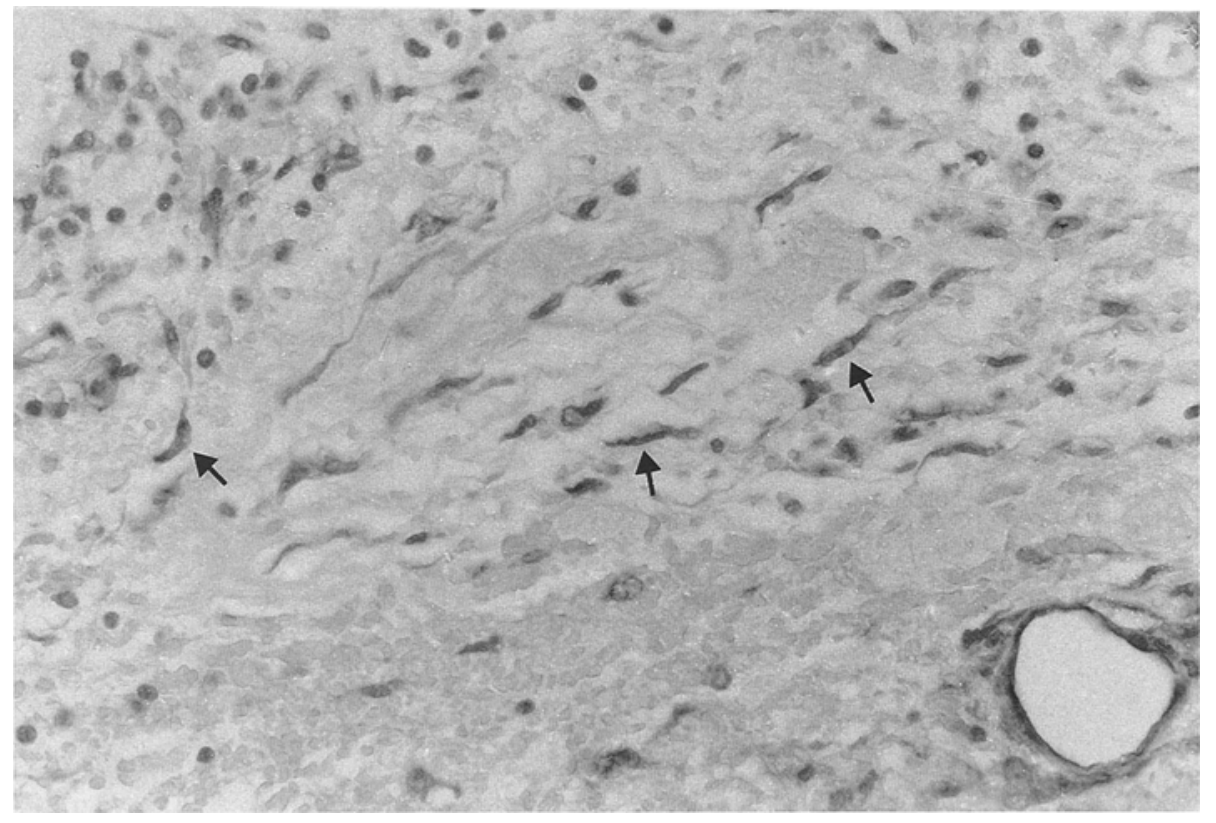

Fig. 1. Alpha-actin positive myofibroblasts (arrows) in a 31-day-old human skin wound; positive staining of the pericytes of a smaller blood vessel (paraffin, APAAP, $480 \times$ ) 
cells of skin muscles (musculi arrectores pili) and in myoepithelial cells of certain skin glands.

The musculi arrectores pili and smooth muscle cells of arterioles also showed a distinct positive staining for desmin. In myoepithelial cells of skin glands no positive reaction for desmin could be found.

Sections without the inclusion of the primary antibody always showed negative staining reactions.

\section{Skin wounds}

In our series, granulation tissue was not detectable in skin lesions of less than 5 days $(n=5)$ duration. In these wounds up to 5 days old no alpha-sma-positive cells could be observed and all specimens were classified as group 0 . Out of 44 skin lesions with typical granulation tissue and a wound age between 5 and 31 days, the wound area in 25 cases contained alpha-sma-positive myofibroblasts in varying amounts. Numerous positively

Table 1. Wound age dependent distribution of alpha-actin positive myofibroblasts in human skin lesions

\begin{tabular}{|c|c|c|}
\hline Wound age & $\begin{array}{l}\text { Total number } \\
\text { of cases }\end{array}$ & $\begin{array}{l}\text { Positive reacting cases } \\
\text { (group } 0,1 \text { or } 2 ; \\
\text { individual age in parentheses) }\end{array}$ \\
\hline $20 \mathrm{~h}$ to $<5$ days & 15 & All group 0 \\
\hline 5 days & 3 & $2(86), 0(66), 0(78)$ \\
\hline 6 days & 1 & $1(77)$ \\
\hline 7 days & 1 & $0(42)$ \\
\hline 8 days & 2 & $2(37), 0(18)$ \\
\hline 9 days & 1 & $0(19)$ \\
\hline 10 days & 2 & $2(28), 0(59)$ \\
\hline 11 days & 2 & $1(27), 1(92)$ \\
\hline 12 days & 2 & $1(60), 0(86)$ \\
\hline 13 days & 3 & $1(89), 1(56), 0(48)$ \\
\hline 14 days & 4 & $1(22), 0(91), 0(40), 0(56)$ \\
\hline 15 days & 1 & $1(22)$ \\
\hline 16 days & 1 & $2(80)$ \\
\hline 17 days & 2 & $2(24), 0(72)$ \\
\hline 18 days & 3 & $2(41), 0(50), 0(37)$ \\
\hline 21 days & 2 & $2(69), 0(25)$ \\
\hline 22 days & 2 & $1(64), 1(71)$ \\
\hline 26 days & 2 & $1(48), 0(54)$ \\
\hline 27 days & 1 & $1(35)$ \\
\hline 28 days & 3 & $1(47), 0(28), 0(57)$ \\
\hline 30 days & 2 & $1(63), 0(82)$ \\
\hline 31 days & 4 & $2(62), 1(79), 1(62), 1(25)$ \\
\hline 38 days & 1 & $0(54)$ \\
\hline 42 days & 1 & $2(62)$ \\
\hline 44 days & 1 & $0(55)$ \\
\hline 46 days & 1 & $0(53)$ \\
\hline 2 months & 1 & $0(65)$ \\
\hline 2 months 13 days & 1 & $2(25)$ \\
\hline 7 months & 1 & $0(26)$ \\
\hline
\end{tabular}

0 : no positive reacting myofibroblasts per microscopic field; 1 : less than 5 positively staining cells per microscopic field; 2 : more than 5 positively staining cells per microscopic field reacting myofibroblasts could be seen especially in wounds between approximately 16 and 31 days duration ( $n=22 ; 5$ cases belonging to group 2 and 9 cases belonging to group 1; Fig. 1). In lesions with a wound age between 5 and 16 days $(n=22) 3$ cases also showed numerous positively staining cells and were therefore classified as group 2. Of these 22 cases 8 were characterized by a few interspersed positively reacting myofibroblasts (group 1). Out of 7 lesions with a wound age of more than 31 days, 2 cases (survival time 6 weeks and 2.5 months respectively) contained large numbers of these cells (group 2). In the remaining cases no positively reacting cells were found apart from typical pericytes of granulation tissue capillaries.

Fibroblastic cells positive for desmin could not be detected within the wound area in our series at all.

\section{Discussion}

The determination of the duration of skin wounds with advancing wound healing is based on several parameters. Time-dependent cellular reactions as well as changes in the distribution of extracellular matrix components such as those reported for fibronectin and various collagens $[3,7]$ - can provide significant information suitable for the estimation of age of skin lesions. Analysis of the initial cellular infiltration of wounds shows timedependent changes which may also be used for wound age determination. The initially migrating neutrophilic granulocytes are progressively replaced by macrophages with multiple phagocytotic properties; this process starts at about 16-24h after wounding [1, for review see 13]. Erythrophagocytosis is detectable in human skin wounds as early as $15-17 \mathrm{~h}$ after wounding. Deposits of hemosiderin resulting from erythrocyte degradation in the interstitial tissue or within macrophages (siderophages) can easily be visualized by the "Berliner-Blau" (Prussian Blue)-reaction 3 or 4 days after wounding, although other authors have found a considerably earlier appearance of hemosiderin in human skin lesions [for review see 13].

The earliest appearance of hematoidin is reported in human skin lesions 3-4 days old, but can also be found in considerably older lesions [13]. Lipid phagocytosing macrophages (lipophages) are first detectable at about 3.5 days and are well established 5 days after wounding [2]. In addition to these inflammatory and/or degenerative cellular events, the process of fibro-proliferation commences. This is characterized by the invasion of the traumatised area by mesenchymal spindle-shaped cells which morphologically are "fibroblasts". They may be derived from immigrating mesenchymal blood cells [12, $14,15]$ or from proliferation of local mesenchymal tissue [18]. Golde et al. [9] showed that in patients undergoing bone marrow grafting, the fibroblasts in the bone marrow stemmed from the recipient, while the blood cells came from the donor. The proliferating fibroblasts that occur during wound healing contain certain subsets of filaments such as alpha-actin $[16,17]$ which, being similar to that in smooth muscle cells, coined for them the term 
"myofibroblasts". Experimental studies showed that on the basis of the content of several intermediate filaments, myofibroblasts can be sub-divided into 4 main groups [20] according to the proportions of the vimentin, alpha-sma-actin and desmin filaments. The origin of myofibroblasts is uncertain but a development from fibroblasts, pericytes, and smooth muscle cells has been postulated [16].

In normal granulation tissue only fibroblasts and actin-containing myofibroblasts occur and no desminpositive myofibroblasts or smooth muscle cells can be identified. The latter cells were reported in hypertrophic scar tissue, fibromatoses, and in granulomas following infection [4]. Similar changes were shown in experimental studies [6, 16]. Skalli et al. [20] investigated human granulation tissue and originally found no actin-containing cells, but an analysis of a larger number of samples did demonstrate them [6]. Desmin-positive myofibroblasts could not be found during normal wound healing.

These observations formed the basis of the hypothesis that an assay of the appearance and/or disappearance of the "myofibroblasts" could be used to estimate the duration of a wound. In this series, typical granulation tissue was first detected in skin lesions as early as 5 days after wounding. Skin wounds of less than about 5 days duration contained no myofibroblasts. This result agrees with the experimental findings of Darby et al. [6] in rats.

In the granulation tissue of $57 \%$ of the skin lesions with a wound age between 5 and 31 days $(n=44)$ myofibroblasts were found. The observation that a certain percentage of cases showed no positive reaction for alpha-actin in proliferating fibroblastic cells confirmed the previous findings of Skalli et al. [20], but an explanation for this fact can not be given at present.

In only 2 of the 7 cases with a wound age more than 31 days (survival time: 6 weeks $/ 2.5$ months) could typical myofibroblasts be found, but were present in large numbers. Darby et al. [6] reported a disappearance of actin-containing cells in skin wounds from rats after 30 days. Since the specimen with a wound age of 2 months and 13 days was obtained from a 25-year-old man any indication that advanced individual age could lead to delayed wound healing could not be demonstrated. On the other hand, the earliest appearance of alpha-sma-positive myofibroblasts was observed in a 5-day-old wound from a 86-year-old female indicating that a significant delay in the appearance of myofibroblasts does not occur due to advanced age of the individuals.

This difference to our results could be explained by species-related differences. It is assumed that biological processes such as wound healing proceed faster in small animals than in man. Therefore, experimental data have to be interpreted with great caution and the results obtained from experimental wound healing cannot simply be transferred to the situation in humans. On the other hand, this contrast to the results of Darby et al. could perhaps be due to limited sampling. Specific data on the number of cases with a wound age of 30 days are not given in that study and no skin wounds with a wound age of more than 30 days were investigated. As in other pub- lications $[6,20]$ no desmin-positive cells were identified in our series indicating that cells with the typical smooth muscle phenotypic expression are not involved in normal wound healing.

The semiquantitative evaluation provided no relevant information for the estimation of wound duration. Large amounts of positively reacting cells could be found in a 5 -day-old wound and one wound more than 2 months old. In addition, the observation that positively reacting myofibroblasts cannot be identified in all specimens and the variation in the amount of reacting cells indicates that the number of these cells in the wound area cannot be used for wound age determination.

In summary, our study provides the following information suitable for a time-estimation of human skin wounds by the immunohistochemical detection of alphasma-positive myofibroblasts in the granulation tissue:

1. Alpha-actin positive cells are first detectable in human granulation tissue in skin wounds approximately 5 days old.

2 . In lesions with a wound age of 31 days or more myofibroblasts still occur in a reduced number of cases.

3. The appearance of alpha-actin-containing cells is not a necessary condition for the formation of granulation tissue in human skin wounds. Therefore negative results allow no estimation of wound age.

4. A relationship between the number of positive reacting myofibroblasts and wound age could not be found and no significant influence of the age of the individuals on the appearance of these cells was observed.

5. During normal wound healing no desmin-positive cells (smooth muscle type) were detectable and indicates that immunohistochemical staining for desmin is not useful for wound age determination.

\section{References}

1. Berg S (1975) Vitale Reaktionen und Zeitschätzungen. In: Mueller B (eds) Gerichtliche Medizin, vol 1. Springer, Berlin Heidelberg New York, pp 326-340

2. Betz P, Penning R, Eisenmenger W (1991) Lipophagen der Haut als zusätzlicher Parameter für die histologische Wundalterschätzung. Rechtsmedizin 1:139-144

3. Betz P, Nerlich A, Wilske J, Tübel J, Wiest I, Penning R, Eisenmenger W (1991) Immunohistochemical localization of fibronectin as a tool for the age determination of human skin wounds. Int J Leg Med 105:21-26

4. Bolmont C, Andujar M, Peyrol S, Grimaud J-A (1991) Desmin expression in fibroblasts of murine periovular granuloma during liver Schistosoma mansoni infection. Differentiation $46: 89-95$

5. Cordell JL, Falini B, Erber WN, Ghosh AK, Abdulaziz Z, MacDonald S, Pulford AF, Stein H, Mason DY (1984) Immunoenzymatic labeling of monoclonal antibodies using immuno complexes of alkaline phosphatase and monoclonal antialkaline phosphatase (APAAP-complex). J Histochem Cytochem 32:219-229

6. Darby I, Skalli O, Gabbiani G (1990) Alpha-smooth muscle actin is transiently expressed by myofibroblasts during experimental wound healing. Lab Invest $63: 21-29$

7. Eisenmenger W, Nerlich A, Glück G (1988) Die Bedeutung des Kollagens bei der Wundaltersbestimmung. Z Rechtsmed $100: 79-100$ 
8. Gabbiani G, Ryan GB, Majno G (1971) Presence of modified fibroblasts in granulation tissue and their possible role in wound contraction. Experientia $27: 549-550$

9. Golde DW, Hocking WG, Quan SG, Sparkes RS, Gale RP (1980) Origin of human bone marrow fibroblasts. Br J Haematol $44: 183-187$

10. Hsu SM, Raine L, Fanger HC (1981) A comparative study of the peroxidase-anti peroxidase method and an avidin-biotin complex method for studying polypeptide hormones with radio immunoassay antibodies. Am J Clin Pathol 75:734-739

11. Majno G, Gabbiani G, Hirschel BJ, Ryan GB, Statkov PR (1971) Contraction of granulation tissue in vitro: similarity to smooth muscle. Science 173:548-550

12. Oehmichen M (1973) Demonstration of hematogenous origin of fibroblasts by parabiosis. Experientia 29:841-842

13. Oehmichen M (1990) Die Wundheilung. Springer, Berlin Heidelberg New York

14. Ross R (1968) The fibroblast and wound repair. Biol Rev 43:51-96

15. Ross R, Everett NB, Tyler R (1970) Wound healing and collagen formation. VI. The origin of the wound fibroblast studied in parabiosis. $J$ Cell Biol 44:645-654
16. Sappino AP, Schürch W, Gabbiani G (1990) Biology of dis ease. Differentiation repertoire of fibroblastic cells: expression of cytoskeletal proteins as markers of phenotypic modulations. Lab Invest 63:144-161

17. Schürch W, Seemayer TA, Lagacé R, Gabbiani G (1984) The intermediate filament cytoskeleton of myofibroblasts: an immunofluorescence and ultrastructural study. Virchows Arch [A] 403: 323-336

18. Silver IA (1973) Local and systemic factors which affect the proliferation of fibroblasts. In: Kulonen E, Karainenem JPK (eds) Biology of fibroblasts. Academic Press, London New York, pp 507-518

19. Skalli O, Gabbiani G (1988) The biology of the myofibroblast: relationship to wound contraction and fibrocontractive diseases. In: Clark RAF, Henson PM (eds) The molecular and cellular biology of wound repair. Plenum Publishing Corporation, New York, pp 373-402

20. Skalli $O$, Schürch $W$, Seemayer $T$, Lagacé $R$, Montandon D, Pittet B, Gabbiani G (1989) Myofibroblasts from diverse pathologic settings are heterogenous in their content of actin isoforms and intermediate filament proteins. Lab Invest $60: 275-285$ 